\title{
The 4Cs of adaptation tracking: consistency, comparability, comprehensiveness, coherency
}

\author{
James D. Ford • Lea Berrang-Ford
}

Received: 30 June 2014 / Accepted: 25 November 2014 / Published online: 10 January 2015

(C) The Author(s) 2015. This article is published with open access at Springerlink.com

\begin{abstract}
Adaptation tracking seeks to characterize, monitor, and compare general trends in climate change adaptation over time and across nations. Recognized as essential for evaluating adaptation progress, there have been few attempts to develop systematic approaches for tracking adaptation. This is reflected in polarized opinions, contradictory findings, and lack of understanding on the state of adaptation globally. In this paper, we outline key methodological considerations necessary for adaptation tracking research to produce systematic, rigorous, comparable, and usable insights that can capture the current state of adaptation globally, provide the basis for characterizing and evaluating adaptations taking place, facilitate examination of what conditions explain differences in adaptation action across jurisdictions, and can underpin the monitoring of change in adaptation over time. Specifically, we argue that approaches to adaptation tracking need to (i) utilize a consistent and operational conceptualization of adaptation, (ii) focus on comparable units of analysis, (iii) use and develop comprehensive datasets on adaptation action, and (iv) be coherent with our understanding of what constitutes real adaptation. Collectively, these form the 4Cs of adaptation tracking (consistency, comparability, comprehensiveness, and coherency).
\end{abstract}

Keywords Climate change $\cdot$ Adaptation tracking $\cdot$ Adaptation $\cdot$ Monitoring and evaluation

\section{Introduction}

The importance of quantifying and monitoring greenhouse gas emissions is widely recognized, providing measurable outcomes by which the effectiveness of climate policy can be assessed. The significance of the United Nations Framework Convention on Climate Change Kyoto Protocol, for example, has been examined with reference to a decrease in carbon dioxide emissions by $16 \%$ among annex-1 nations between 1990 and 2012 or with respect to global emissions which increased by $52 \%$ over the same period (PBL 2013). Other studies, meanwhile, have examined how various factors affect mitigation action across nations (Tubi et al. 2012; Dolsak 2001, 2009;

J. D. Ford $(\bowtie) \cdot$ L. Berrang-Ford

Department of Geography, McGill University, Montreal, QC H3A0B9, Canada

e-mail: James.ford@mcgill.ca

L. Berrang-Ford

e-mail: Lea.berrangford@mcgill.ca 
Baettig and Bernauer 2009). Our ability to similarly evaluate adaptation policy is limited. As chapters in Working Group II (WGII) to the Fifth United Nations Intergovernmental Panel on Climate Change (IPCC) Assessment note, we have only limited and fragmented evidence on adaptation progress globally, reflected in the absence of measurable outcomes or indicators by which adaptation can be evaluated and compared, while our knowledge on what conditions explain differential progress on adaptation across nations, regions, and sectors, is limited (Mimura and Pulwarty 2014; Noble and Huq 2014; Dupuis and Biesbroek 2013a). These deficiencies, in turn, constrain our ability to measure progress: for adaptation, there is no 1990 baseline.

These are significant gaps in the emerging adaptation science, especially given the increased importance of adaptation in climate policy and commitment to funding and adaptation program development by governments at various scales, international institutions, nongovernmental organizations (NGOs), and the private sector (Moss et al. 2013; Editorial 2013). Indeed, there is substantial and growing interest in the research and policy community on the need to develop frameworks and indicators for examining adaptation across nations and over time (Ford et al. 2013; Dupuis and Biesbroek 2013a). Despite the need for such work, the literature is lacking the more normative, index-based approaches required at this scale. As Swart et al (2014) argue, most of the research on adaptation focuses on characterizing a small number of cases to examine whether adaptation is occurring and why it is successful or not in particular contexts. This is a necessary and important work, but the insights developed are largely context dependent, with such approaches not well-suited for asking broader level questions about adaptation, including the following: Is adaptation taking place? If so, who is adapting, to what, where, and what types of adaptation are being undertaken? Are we adapting more over time? Which nations, regions, and sectors are leading on adaptation? What elements of adaptive capacity are most significant in determining adaptation action? Why is adaptation progressing in one country or region but not another? What conditions affect adaptation success? (Berrang-Ford et al. 2014; Swart et al. 2014; Preston et al. 2014; Dupuis and Biesbroek 2013a; Berrang-Ford et al. 2015).

Addressing these questions requires studies which seek standardization, generalization, simplification of complexity, and develop broad scale insights. Research methods and techniques used by the adaptation community to-date, however, have generally failed to engage with such approaches, largely eschewing the critical need for breadth as a compliment to research depth. In doing so, adaptation is significantly lagging mitigation in the development of tools, methodologies, and indicators. A number of conceptual, methodological, and institutional challenges have been identified to constrain the development of such work herein: there is wide ranging debate, for instance, on what actually constitutes actual adaptation in general and successful adaptation in particular, few comprehensive datasets on adaptation exist, and the importance of comparative studies on adaptation progress has yet to be fully recognized by the adaptation community and funding agencies (Dupuis and Biesbroek 2013a; Preston et al. 2014; Murtinho and Hayes 2012; Swart et al. 2014). These challenges are not intractable and have been addressed in other areas including global health, international development, and political science.

In this paper, we respond to the need for alternative research approaches in the adaptation field by proposing key components of research design necessary to develop rigorous, systematic, transparent, and ultimately usable insights from which the current status of adaptation across nations and sectors can be characterized, evaluated, and compared. In doing so, the paper builds upon the work of Swart et al (2014) who identify the need for a science of adaptation, by seeking to bring conceptual and methodological clarity to the emerging adaptation tracking work. As such, the paper does not present an assessment tool but outlines the importance of studies being consistent and clear in how adaptation is defined, focusing on 
comparable units of analysis, using and developing comprehensive datasets on adaptation action, and being coherent with our understanding of what constitutes "real" adaptation.

\section{The emergence of adaptation tracking research}

The last decade has witnessed a rapid increase in adaptation research (Massey and Huitema 2013; Khan and Roberts 2013; Preston et al. 2014), which has recently begun to examine the actual experience of adaptation, assessing the extent and nature of adaptations taking place as well as their success or effectiveness in reducing vulnerability (Ford et al. 2013). The majority of this work focuses on specific policies or programs and has been driven by the needs of development organizations, donors, and governments for measuring the success of supported adaptation initiatives (Villaneuva 2011; Red Cross Red Crescent 2013; Sherman and Ford 2014; Biesbroek et al. 2010; Lamhauge et al. 2013; Brooks et al. 2011b, 2013; Berrang-Ford et al. 2014; Bradley et al. 2014). This research has prioritized developing in-depth, context specific, and primarily qualitative insights on the adaptation process as a basis for evaluating and monitoring intervention/program performance, reflecting the local/regional nature of adaptations of focus in this work. These studies actively seek to work with decision makers to evaluate why and how an adaptation worked, or did not, in a particular context. Methods for achieving this are varied but generally follow process evaluation approaches, where characteristics of adaptation development and implementation are compared to theoretically derived components of adaptation success and best practice (Ford et al. 2013). Evaluation criteria, including effectiveness, efficiency, equity, legitimacy, flexibility, acceptability, mainstreaming, and sustainability, are generally employed in this work to assess adaptations, primarily using qualitative approaches (interviews, focus groups, surveys), although self-reporting metrics such as rating scales, psychometric measures, etc., have also been advocated (de Bruin et al. 2009; Yohe and Tol 2002; Brooks et al. 2011b, 2013; Swim et al. 2011). The strong emphasis on context specificity in this work reflects the widely held, yet increasingly critiqued, perception that adaptation is primarily a local process (Preston et al. 2014).

A much smaller body of scholarship is concerned with the adaptation landscape at regional to global levels, examining if and how adaptation is taking place across nations, how this is changing over time, and identifying predictor's of adaptation action (Ford et al. 2013; BerrangFord et al. 2011; Gagnon-Lebrun and Agrawala 2007; Lesnikowski et al. 2011; Eisenack and Stecker 2012; Krysanova et al. 2010; Massey and Bergsma 2008; Keskitalo 2010; Biesbroek et al. 2010; Reckien et al. 2014; Porter et al. 2014) (Table 1). We term this work "adaptation tracking." In this nascent field of research, the development and use of indicators is important, providing a systematic and standardized means for evaluating and comparing adaptation over time (i.e., longitudinal assessment) and across regions, countries, and sectors (i.e., case comparison) (Hinkel 2011). The intent of this work is to generalize, quantify, and monitor adaptation for purposes of informing decision makers on the extent to which statements of recognition on adaptation are translating into on-the-ground actions, to learn how different policy contexts are addressing adaptation, to identify and prioritize adaptation needs, to monitor progress on adaptation over time, and to examine factors driving adaptation (Berrang-Ford et al. 2014).

The emergence of adaptation tracking research reflects a number of factors. Firstly, as the adaptation field has expanded, there has been increasing frustration that investments in adaptation research have not translated into action, with a number of recent articles noting that this stems from the underlying, untested heuristics framing much adaptation work, and dominance of practice orientated case study methodologies to the exclusion of other approaches (Swart et al. 
Table 1 Examples of approaches to tracking adaptation

\begin{tabular}{|c|c|c|c|}
\hline $\begin{array}{l}\text { Emphasis of } \\
\text { the approach }\end{array}$ & Description & Relevant measures & Sources of information \\
\hline $\begin{array}{l}\text { Progress } \\
\text { e.g., Gagnon- } \\
\text { Lebrun and } \\
\text { Agrawala } \\
\quad(2007)\end{array}$ & $\begin{array}{l}\text { - Emphasis on progress } \\
\text { made } \\
\text { by governments, } \\
\text { NGOs, } \\
\text { private sector etc. from } \\
\text { articulating adaptation } \\
\text { goals } \\
\text { to planning and } \\
\text { implementation } \\
\text { - Views concrete action as } \\
\text { more } \\
\text { valuable than } \\
\text { groundwork }\end{array}$ & $\begin{array}{l}\text { - Have there been } \\
\text { vulnerability and impact } \\
\text { assessments tailored to } \\
\text { the scale, sector, region } \\
\text { of focus? } \\
\text { - Have different adaptation } \\
\text { options been identified? } \\
\text { - Have adaptation policies } \\
\text { been formulated? } \\
\text { - Has adaptation been } \\
\text { explicitly incorporated } \\
\text { into projects? } \\
\text { - Have adaptation measures } \\
\text { been implemented? } \\
\text { - Has there been learning } \\
\text { from past adaptation } \\
\text { experience? }\end{array}$ & $\begin{array}{l}\text { - UNFCCC National } \\
\text { Communications } \\
\text { - UNFCCC Private Sector } \\
\text { Initiative } \\
\text { - National/regional/sectoral } \\
\text { adaptation assessments } \\
\text { - Peer reviewed scholarship } \\
\text { - Organization websites } \\
\text { (e.g., government, civil } \\
\text { society organization, } \\
\text { health authority) } \\
\text { - Legislation } \\
\text { - Adaptation databases }\end{array}$ \\
\hline $\begin{array}{l}\text { Process } \\
\text { e.g., Fussel (2008) } \\
\text { Mukheibir and } \\
\quad \text { Ziervogel } \\
\quad(2008)\end{array}$ & $\begin{array}{l}\text { - Emphasis on procedural } \\
\text { aspects of adaptation } \\
\text { policy/planning } \\
\text { - Views coherent policy- } \\
\text { making process to be } \\
\text { more likely to produce } \\
\text { effective adaptation }\end{array}$ & $\begin{array}{l}\text { - Is there a clear procedural } \\
\text { structure in the policy- } \\
\text { making process? } \\
\text { - Is there evidence of } \\
\text { localized impact } \\
\text { assessments? } \\
\text { - Is there evidence of } \\
\text { building M\&E into the } \\
\text { adaptation process? } \\
\text { - Is there evidence of } \\
\text { inclusion of key } \\
\text { stakeholders? } \\
\text { - Have adaptation concerns } \\
\text { been prioritized in the } \\
\text { policy-making domain? } \\
\text { - Has adaptation been } \\
\text { incorporated into the } \\
\text { development process? } \\
\text { - Has adaptation been } \\
\text { incorporated into } \\
\text { Disaster Risk Reduction } \\
\text { programs? } \\
\text { - Is there a prioritization } \\
\text { among adaptation } \\
\text { policies } \\
\text { - How are uncertainties } \\
\text { being managed? }\end{array}$ & $\begin{array}{l}\text { - Adaptation planning } \\
\text { documents } \\
\text { Adaptation program } \\
\text { descriptions } \\
\text { - Consultation documents } \\
\text { - Boundary organizations } \\
\text { - Institutional structure } \\
\text { analysis } \\
\text { - Adaptation readiness } \\
\text { evaluations } \\
\text { - Program development } \\
\text { - Decision maker surveys }\end{array}$ \\
\hline $\begin{array}{l}\text { Diversity } \\
\text { e.g., Carmin } \\
\text { et al (2012) } \\
\text { Lesnikowski } \\
\text { et al (2011; } \\
\text { 2014) }\end{array}$ & $\begin{array}{l}\text { - Emphasis on the need } \\
\text { to tackle } \\
\text { vulnerability across } \\
\text { sectors } \\
\text { - Values variety of } \\
\text { adaptation } \\
\text { policies } \\
\text { - Values diversity of } \\
\text { impacts and } \\
\text { sectors addressed }\end{array}$ & $\begin{array}{l}\text { - How many/which } \\
\text { impacts are being } \\
\text { addressed? } \\
\text { - How many/which sectors } \\
\text { are being strengthened? } \\
\text { - Which policy typologies } \\
\text { are being used (e.g., } \\
\text { direct management vs. } \\
\text { soft and open policies) }\end{array}$ & $\begin{array}{l}\text { - Government policy } \\
\text { summaries } \\
\text { - Sectoral } \\
\text { adaptation reports } \\
\text { (e.g., transportation } \\
\text { ministries, utilities } \\
\text { ministries, } \\
\text { port authorities) } \\
\text { - Global/regional/ } \\
\text { local surveys of } \\
\text { adaptation activity }\end{array}$ \\
\hline
\end{tabular}


Table 1 (continued)

\begin{tabular}{|c|c|c|c|}
\hline $\begin{array}{l}\text { Emphasis of } \\
\text { the approach }\end{array}$ & Description & Relevant measures & Sources of information \\
\hline & $\begin{array}{l}\text { - Highlights the } \\
\text { importance of } \\
\text { diverse typologies to } \\
\text { address } \\
\text { different problems }\end{array}$ & & $\begin{array}{l}\text { - UNFCCC National } \\
\text { Communications } \\
\text { - IPCC Assessment } \\
\text { Reports }\end{array}$ \\
\hline $\begin{array}{l}\text { Quality } \\
\text { e.g., Dupuis } \\
\text { and } \\
\text { Biesbroek } \\
\text { (2013) }\end{array}$ & $\begin{array}{l}\text { - Evaluates the success of } \\
\text { policy on } \\
\text { increasing resilience } \\
\text { Emphasis on } \\
\text { purposeful and } \\
\text { substantive aspects of } \\
\text { adaptation policy } \\
\text { - Outcome oriented, } \\
\text { examining the quality } \\
\text { of existing adaptation } \\
\text { policies }\end{array}$ & $\begin{array}{l}\text { - Is the policy explicitly } \\
\text { designed to manage the } \\
\text { impacts of climate } \\
\text { change? } \\
\text { - Does the policy reduce } \\
\text { climate change } \\
\text { vulnerability? }\end{array}$ & $\begin{array}{l}\text { - Documents } \\
\text { monitoring } \\
\text { implementation } \\
\text { - Independent } \\
\text { program } \\
\text { evaluation } \\
\text { - NGO/private sector } \\
\text { assessments } \\
\text { - Public and private } \\
\text { policy analyses } \\
\text { - Peer reviewed } \\
\text { scholarship }\end{array}$ \\
\hline
\end{tabular}

2014; Berrang-Ford et al. 2014; Preston et al. 2014; Massey et al. 2014; Burton and Mustelin 2013; Bassett and Fogelman 2013). Herein, adaptation tracking studies are recognized as essential for theorizing and testing fundamental assumptions about adaptation based on cross-national comparative analysis of how different contexts and jurisdictions approach adaptation, and for learning what determines success of policy intervention (Dupuis and Biesbroek 2013a). Fundamental questions of importance here would include examining what components of adaptive capacity are most important for determining successful adaptation, how they operate in different contexts, and what factors operate as effect modifiers (Berrang-Ford et al. 2014). While such arguments for the importance of adaptation tracking have been primarily articulated in an academic setting, the questions raised are essential for developing a comprehensive evidence base on what works in an adaptation context.

Secondly, the adaptation tracking field is emerging in response to the needs of national governments, international organizations, and the scientific community, with NGOs and the private sector also identifying interest (Sovacool et al. 2012; Lesnikowski et al. 2014; Brooks et al. 2013; Editorial 2013; Lamhauge et al. 2013; Biagini et al. 2014). This reflects a number of factors - summarized in Table 2-including the need to evaluate whether adaptation support is translating into actions, identify future priorities, ensure resources are being invested in areas with the greatest need, and inform governance systems on the current status and gaps in adaptation action (Ford et al. 2013). As adaptation funds have begun to be disbursed through the United Nations Framework Convention on Climate Change (UNFCCC), for example, Parties, NGOs, and United Nations (UN) bodies have expressed the need to examine the success of funds invested for accountability purposes and to ensure resources are being effectively utilized, with the Cancun Agreement explicitly recognizing the need to monitor and review adaptation across nations. Governments at various levels have also expressed interest in measuring progress towards meeting the objectives of national adaptation strategies, learning how other jurisdictions are adapting, and evaluating progress over time (Lesnikowski et al. 2014).

For purposes of tracking progress, adaptation is a different problem from mitigation, which can be assessed vis-à-vis greenhouse gas emissions. The ultimate goal of adaptation is to reduce harm to future climate change and, theoretically, could be assessed with reference to 
Table 2 Potential users of adaptation tracking studies and the questions that can be answered

\begin{tabular}{|c|c|}
\hline Potential users of adaptation tracking research & Questions adaptation tracking research can help answer \\
\hline $\begin{array}{l}\text { International organizations that fund adaptation } \\
\text { (e.g., World Bank, regional development } \\
\text { banks, UN } \\
\text { organizations) }\end{array}$ & $\begin{array}{l}\text { - Are adaptation programs stimulating action on the } \\
\text { ground (e.g., GEF programs)? } \\
\text { - Which nations have the greatest need for adaptation } \\
\text { support? } \\
\text { - Are actions consistent with the risks posed by climate } \\
\text { change? } \\
\text { - How is adaptation changing over time? }\end{array}$ \\
\hline $\begin{array}{l}\text { UNFCCC (Cancun Agreement Decision 1, } \\
\text { paragraphs } \\
14 \text { and } 20 \text { explicitly recognizes need to } \\
\text { monitor and } \\
\text { review adaptation) }\end{array}$ & $\begin{array}{l}\text { - Are Nations meeting their responsibilities to } \\
\text { adaptation as set out in the UNFCCC? } \\
\text { - How can adaptation funds be most effectively invested? } \\
\text { - In what areas and regions is technology and } \\
\text { knowledge transfer for adaptation needed? } \\
\text { - Are we progressing on adaptation? }\end{array}$ \\
\hline $\begin{array}{l}\text { Government (various scales: national, } \\
\text { regional, municipal) }\end{array}$ & $\begin{array}{l}\text { - How does performance compare to other governments? } \\
\text { - Are there transferable lessons from other governments? } \\
\text { - Is progress being made to meet adaptation planning } \\
\text { objectives? } \\
\text { - Where are the gaps in adaptation? } \\
\text { - Are projected risks being addressed? }\end{array}$ \\
\hline Research community & $\begin{array}{l}\text { - Is the adaptation response consistent with the risks posed? } \\
\text { - What factors explain adaptation progress and do they vary } \\
\text { across region, nation, sector? } \\
\text { - Which nations are leaders in adaptation and what lessons } \\
\text { do they hold for promoting adaptation globally? }\end{array}$ \\
\hline NGOs & $\begin{array}{l}\text { - Which nations and what sectors need adaptation support? } \\
\text { - Is the international response to adaptation consistent with } \\
\text { the risks } \\
\text { posed and is it progressing? }\end{array}$ \\
\hline Private firms/consultancy & $\begin{array}{l}\text { - What are available methods to measure adaptation } \\
\text { progress? } \\
\text { - What types of adaptation initiatives currently exist } \\
\text { elsewhere } \\
\text { and can } \\
\text { be transferred? } \\
\text { - How can the policy process be changed to induce more } \\
\text { effective adaptation? }\end{array}$ \\
\hline
\end{tabular}

avoided future impacts, where loss metrics (e.g., morbidity, mortality, economic loss attributable to climate) could be monitored to evaluate progress towards a more adaptable society. The use of such metrics, however, depends on avoided impacts being observable, measureable, and attributable to adaptation, thus limiting the applicability of outcome indicators given conceptual and methodological challenges (Adger et al. 2005; Brooks et al. 2011a; Ford et al. 2013). Proxies are therefore needed for developing a baseline on the current status of adaptation and for measuring progress (Table 3). The majority of studies use reporting on adaptation policies, programs, and initiatives as a proxy on the extent to which adaptation is taking place and for examining potential effectiveness in reducing vulnerability (e.g., adaptation databases, UNFCCC National Communications, peer reviewed and grey literature, national adaptation assessments, adaptation planning documents etc.) (Table 3). While such reporting is an imperfect proxy subject to reporting bias, challenges associated with implementation deficit, and varying level of detail provided (Dupuis and Knoepfel 2013b; Hupe et al. 2014), there are 
few alternative data sources available across nations for tracking purposes that provide the level of detail necessary (Bizikova et al. 2015; Sud et al. 2015; Gagnon-Lebrun and Agrawala 2007). Moreover, such reporting has been used for comparable policy tracking for global health and social policy to identify and monitor general policy trends, locate leaders and laggards, and examine change over time (Ford et al. 2013; Earle et al. 2011; Heymann et al. 2011; Heymann and McNeill 2013).

\section{Methodological considerations for adaptation tracking}

The emerging adaptation tracking subfield has developed a baseline understanding of adaptation in specific contexts, piloting different approaches, and methods. Yet the polarized opinion and contradictory findings on the current state of adaptation are indicative of a weak understanding of what adaptation and adaptation progress means (Noble and Huq 2014; Dupuis and Biesbroek 2013a) (Table 1), while there is little agreement or standardization on how adaptation reporting should be used for adaptation tracking purposes. This in part reflects the complexity of adaptation, although the conceptual and methodological challenge of tracking adaptation is not unique to climate policy, with a comparable scholarship focusing on problems of similar scope (e.g., global health, social policy). To inform the development of approaches for adaptation tracking, we draw upon this literature and emerging work in an adaptation context to explicitly outline key methodological considerations necessary for global adaptation tracking research to produce systematic, rigorous, comparable, and usable insights that can (i) capture the current state of adaptation across nations, (ii) provide the basis for characterizing and evaluating adaptations taking place in different settings, and (iii) underpin the monitoring of change in adaptation over time.

Borrowing from systematic data collection approaches in global health, and based on the foundation of empirical study design, we collectively term these the 4Cs of adaptation tracking (Fig. 1). In doing so, we are explicitly drawing on two key contributions within public health from which we seek to translate lessons for adaptation research. Firstly, the field of public health has, and continues to be, a leader in the development and application of methods for systematic approaches to literature review, seeking transparent and explicit methods for evidence synthesis (Berrang-Ford et al. 2015). Though traditionally confined to health and health-related fields, systematic approaches to evidence synthesis provide significant opportunity for grappling with diverse evidence of climate change adaptation, and we have herein seen recent emergence in the use of systematic review approaches within the adaptation scholarship (Hardee and Mutunga 2010; Murtinho and Hayes 2012; Biesbroek et al. 2013; Kamau and Mwaura 2013). Second, in the 1980s, public health scholars collaboratively developed an integrated index to track health morbidity and mortality broadly across time and space, leading to the creation of the disability adjusted life year (DALY) and the first Global Burden of Disease Study (GBDS) in 1990 (Murray et al. 1994). A seemingly insurmountable challenge, and highly controversial at the time, these efforts have contributed substantively to systematic tracking of global health, and stimulated a new discipline in health metrics. Though global in focus, the GBDS has motivated broader methodological innovation in measuring health impact, including more localized metrics for tracking health burden. We see important parallels here with climate adaptation and seek to stimulate a similar move towards methodological development of innovative approachesthough not unified metrics like the DALY - for tracking global adaptation. Underpinning the GBDS was the goal of seeking comprehensive, consistent, and comparable methods for evaluating health burden globally. We thus draw conceptually from the GBDS here, proposing the 4Cs of adaptation tracking. 
Table 3 Data sources used in adaptation tracking research

\begin{tabular}{|c|c|c|c|}
\hline Data sources & Context of use & Strengths & Limitations \\
\hline $\begin{array}{l}\text { National } \\
\text { Communications } \\
\text { to the UNFCCC }\end{array}$ & $\begin{array}{l}\text { - Examine status of adaptation in } \\
\text { annex } 1 \text { nations (Lesnikowski } \\
\text { et al. 2011; Gagnon-Lebrun and } \\
\text { Agrawala 2007) and globally } \\
\text { (Lesnikowski et al. 2013) } \\
\text { (creation of adaptation index) } \\
\text { - Identify adaptation predictors } \\
\text { globally (Lesnikowski et } \\
\text { al. 2014) }\end{array}$ & $\begin{array}{l}\text { - Standardized, } \\
\text { systematic, } \\
\text { transparent data } \\
\text { collection } \\
\text { - Regular reporting } \\
\text { for annex-1 } \\
\text { nations } \\
\text { - National-level data } \\
\text { globally } \\
\text { - Accessible online } \\
\text { in one location }\end{array}$ & $\begin{array}{l}\text { - Not available } \\
\text { for all nations } \\
\text { - Primarily } \\
\text { mitigation } \\
\text { focused, } \\
\text { limited } \\
\text { detail on } \\
\text { adaptation } \\
\text { - Reporting bias } \\
\text { - National focus }\end{array}$ \\
\hline $\begin{array}{l}\text { Published climate } \\
\text { initiatives }\end{array}$ & $\begin{array}{l}\text { - Assess climate preparedness in UK } \\
\text { urban areas (Heidrich et al. 2013; } \\
\text { Reckien et al. 2014) (creation of } \\
\text { climate preparedness index) }\end{array}$ & $\begin{array}{l}\text { - Detailed } \\
\text { information on } \\
\text { adaptation } \\
\text { initiatives and } \\
\text { programs } \\
\text { - Widely available } \\
\text { documents (in a } \\
\text { high income } \\
\text { context) }\end{array}$ & $\begin{array}{l}\text { - Lack of } \\
\text { standardization } \\
\text { in } \\
\text { reporting } \\
\text { - Discrepancies in } \\
\text { reports } \\
\text { - Resource } \\
\text { intensive: } \\
\text { requires the } \\
\text { identification, } \\
\text { retrieval, and } \\
\text { collation } \\
\text { of documents }\end{array}$ \\
\hline Website content & $\begin{array}{l}\text { - Document civil society action on } \\
\text { adaptation with regards health in } \\
\text { Canada (Poutiainen et al. 2013) } \\
\text { - Identify community based adaptation } \\
\text { actions in Africa (Mannke 2011) } \\
\text { - Identify OECD actions to prepare for } \\
\text { impacts of climate change on } \\
\text { infectious disease (Panic and } \\
\text { Ford 2013) }\end{array}$ & $\begin{array}{l}\text { - Detailed } \\
\text { information on } \\
\text { adaptation } \\
\text { initiatives and } \\
\text { programs } \\
\text { - Diversity of } \\
\text { adaptations } \\
\text { reported and } \\
\text { captured } \\
\text { - Diversity of } \\
\text { reporting scales } \\
\text { - On-the-ground } \\
\text { adaptation reporting }\end{array}$ & $\begin{array}{l}\text { - Outdated } \\
\text { content } \\
\text { - Identification, } \\
\text { retrieval } \\
\text { and collation } \\
\text { of information } \\
\text { challenges } \\
\text { - Lack of } \\
\text { standardization } \\
\text { - Reporting bias } \\
\text { based on } \\
\text { technological } \\
\text { capacity } \\
\text { - Varying detail } \\
\text { on } \\
\text { adaptation }\end{array}$ \\
\hline $\begin{array}{l}\text { UNFCCC Private } \\
\text { Sector Initiative }\end{array}$ & $\begin{array}{l}\text { - Scoping of the current state of } \\
\text { adaptation in the private sector } \\
\text { (Surminski 2013) }\end{array}$ & $\begin{array}{l}\text { - Standardized } \\
\text { reporting template } \\
\text { - Information on } \\
\text { private sector }\end{array}$ & $\begin{array}{l}\text { - Limited } \\
\text { coverage } \\
\text { - Reporting bias } \\
\text { - Limited detail } \\
\text { on } \\
\text { actions }\end{array}$ \\
\hline $\begin{array}{l}\text { Peer reviewed } \\
\text { journal articles }\end{array}$ & $\begin{array}{l}\text { - Characterize the nature and extent of } \\
\text { adaptation globally (Berrang-Ford } \\
\text { et al. 2011), in annex-1 nations (Ford } \\
\text { et al. 2011), in high risks areas in } \\
\text { cluding the Arctic and mountain re } \\
\text { gions (Ford et al. 2014; McDowell } \\
\text { et al. 2014), among households in }\end{array}$ & $\begin{array}{l}\text { - Easily accessible, } \\
\text { rapid assessment } \\
\text { - High quality } \\
\text { reporting from } \\
\text { varying scales }\end{array}$ & $\begin{array}{l}\text { - Reporting bias } \\
\text { - Lack of } \\
\text { standardization } \\
\text { - Varying detail } \\
\text { on } \\
\text { adaptation }\end{array}$ \\
\hline
\end{tabular}

- Comparable - National focus 
Table 3 (continued)

\begin{tabular}{|c|c|c|c|}
\hline Data sources & Context of use & Strengths & Limitations \\
\hline $\begin{array}{l}\text { National } \\
\quad \text { Adaptation } \\
\text { Strategies }\end{array}$ & $\begin{array}{l}\text { - Evaluation of national level adaptation } \\
\text { in the EU (Biesbroek et al. 2010; } \\
\text { Massey and Bergsma 2008) }\end{array}$ & $\begin{array}{l}\text { - Standardized and } \\
\text { systematic } \\
\text { - National-level } \\
\quad \text { data }\end{array}$ & $\begin{array}{l}\text { - Reporting bias } \\
\text { to } \\
\text { countries with } \\
\text { high capacity } \\
\text { - Data exists } \\
\text { for European } \\
\text { countries } \\
\text { exclusively }\end{array}$ \\
\hline $\begin{array}{l}\text { Peer reviewed and } \\
\text { grey literature }\end{array}$ & $\begin{array}{l}\text { - Survey on the state of adaptation in } \\
\text { the UK (Tompkins et al. 2010) } \\
\text { - Survey on the state of adaptation in arid } \\
\text { and semi-arid regions (Ford et al. } \\
\text { 2014; Sud et al 2015; Bizikova et al } \\
\text { 2015) }\end{array}$ & $\begin{array}{l}\text { - Depth of } \\
\text { information and } \\
\text { diversity of } \\
\text { adaptations } \\
\text { captured } \\
\text { - Diversity of } \\
\text { conceptual } \\
\text { frameworks }\end{array}$ & $\begin{array}{l}\text { - Time } \\
\text { requirements } \\
\text { - Lack of } \\
\text { standardization } \\
\text { - Varying focus, } \\
\text { detail, } \\
\text { and quality }\end{array}$ \\
\hline Legislation & $\begin{array}{l}\text { - Number of laws with adaptation focus } \\
\text { (Townshend et al. 2013) }\end{array}$ & $\begin{array}{l}\text { - Broad scope } \\
\text { - National-level } \\
\text { data available } \\
\text { globally }\end{array}$ & $\begin{array}{l}\text { - Legislative } \\
\text { approach not } \\
\text { taken in all } \\
\text { countries } \\
\text { - Institutional } \\
\text { contexts } \\
\text { vary by nation } \\
\text { - Formal laws not } \\
\text { necessarily } \\
\text { indicative } \\
\text { of action }\end{array}$ \\
\hline $\begin{array}{l}\text { Surveys with } \\
\text { policy makers }\end{array}$ & $\begin{array}{l}\text { - Survey of elite policy makers in } 36 \mathrm{EU} \\
\text { nations to examine development of } \\
\text { national level adaptation policies and } \\
\text { practices (Massey et al. 2014) }\end{array}$ & $\begin{array}{l}\text { - Document } \\
\text { current state } \\
\text { of action on } \\
\text { adaptation } \\
\text { - Standardization } \\
\text { - Not limited by } \\
\text { what is reported } \\
\text { in documents } \\
\text { - Depth of insights }\end{array}$ & $\begin{array}{l}\text { - Challenge of } \\
\text { getting } \\
\text { sufficient } \\
\text { response } \\
\text { rate within and } \\
\text { across nations } \\
\text { - Time intensive }\end{array}$ \\
\hline
\end{tabular}

Each of the Cs is central to adaptation tracking, regardless of whether the primary aim is comparing adaptation progress across cases or longitudinal tracking. Where possible, we use examples to illustrate application of the Cs, noting that there are no studies as yet and to our knowledge, that perform well across all components. Indeed, integrating all the 4Cs into research design presents a significant challenge for the adaptation tracking community. We use an example for our work in Table 4 to demonstrate the application of the $4 \mathrm{Cs}$.

\subsection{Consistency}

If progress on adaptation is to be monitored over time and compared across nations, a consistent and operational conceptualization of adaptation is needed so that any documented differences or change are not a function of definitional inconsistency. The commonly used IPCC (2007) definition of adaptation as "adjustments in natural or human systems in response 


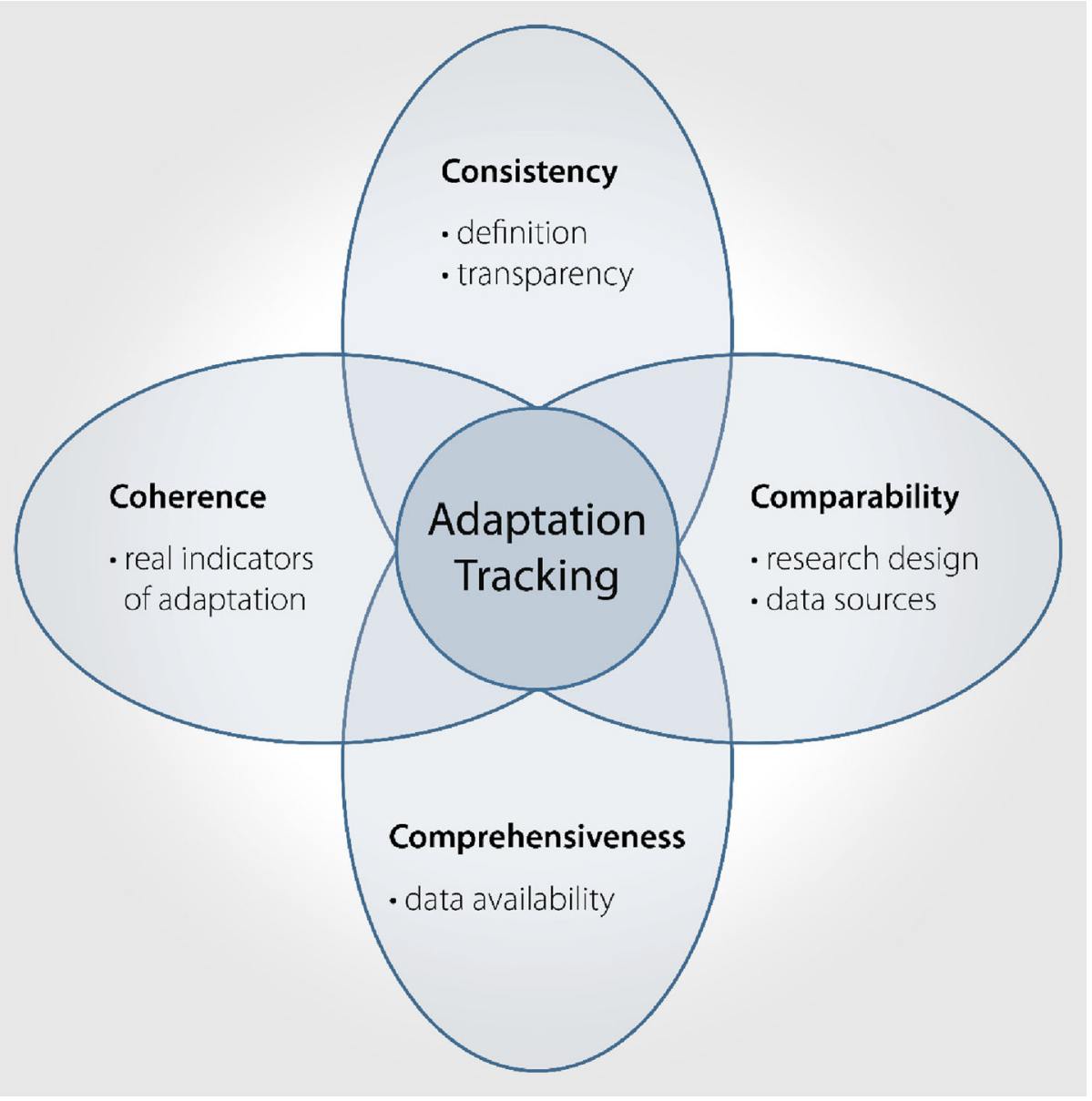

Fig. 1 The 4Cs of adaptation tracking

to actual or expected climate stimuli and their effects," lacks specificity for tracking, where the first task is to identify what actually counts as adaptation. This can be challenging, with adjustments potentially taking a myriad of forms and functions, and may involve specific responses to a known risk or seek to enhance overall capacity to adapt, can be autonomous or planned, focus on reducing present days risks or have a future focus, and may be completely or only partially motivated by climate change (Smit et al. 1999, 2000; Smithers and Smit 1997; Noble and Huq 2014). Perspectives on what is adaptation thus differ widely, determining the extent to which studies are able to find evidence of adaptation taking place; this fuzziness in the scope and boundaries of adaptation has been termed the dependent variable problem (Dupuis and Biesbroek 2013a).

The challenge of specifying what counts as adaptation poses a significant problem for adaptation tracking. Expecting all adaptation studies to use a common conceptualization of adaptation is unrealistic, however, evidenced in the context of similar challenges facing efforts to measure vulnerability (Hinkel 2011; Klein 2009; Klein and Moehner 2011). Indeed, the plurality of definitional starting points can bring diverse insights to measuring adaptation progress. Notwithstanding, tracking studies need to be internally consistent in their definition 


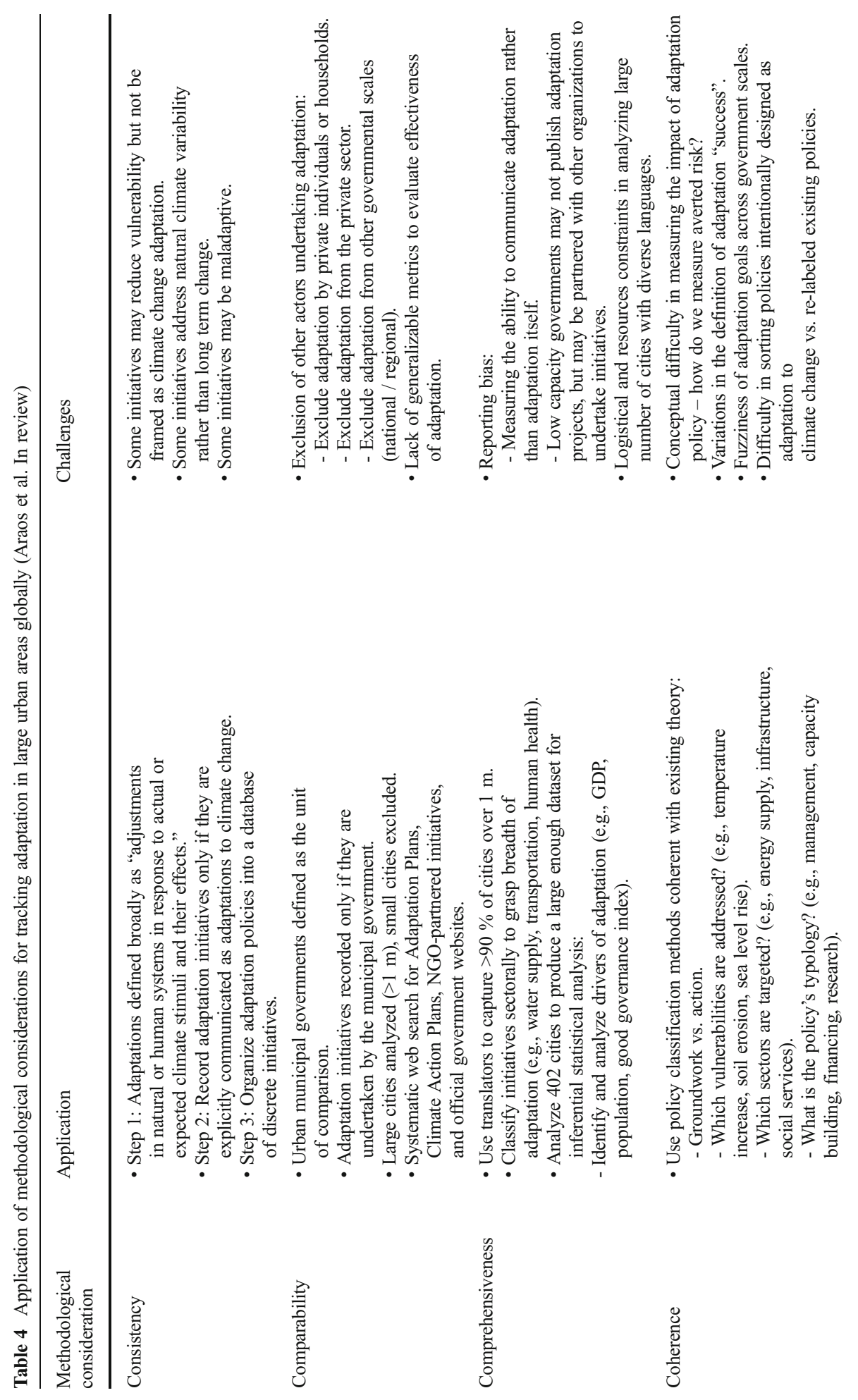




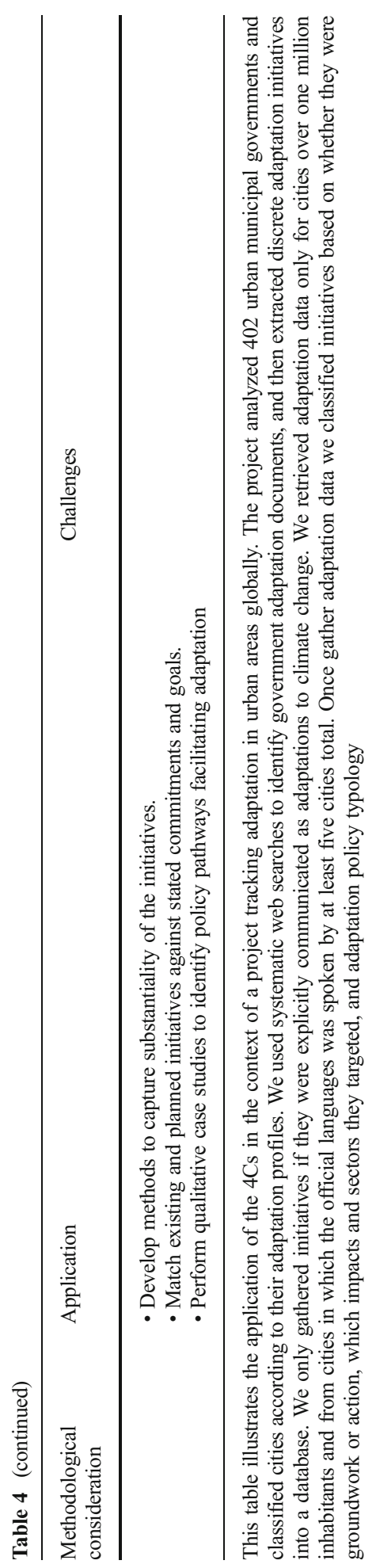


of adaptation if comparing over space and time, transparent in defining inclusion and exclusion criteria for what they consider as adaptation to allow for replication of the study by other research teams, and clearly acknowledge the limits implied by the definition used.

Two alternate conceptualizations of adaptation offer a starting point for tracking studies. A narrow view of adaptation would focus on identifying, characterizing, and monitoring purposefully designed responses to address climate change impacts that contribute to reducing vulnerability and/or taking advantage of new opportunities (Dupuis and Biesbroek 2013a). This follows from arguments that climate change poses unique risks which require specific policies to address future vulnerabilities (Adger and Barnett 2009; O'Brien 2012; Smith et al. 2011; Eakin et al. 2014). A broad view of adaptation would consider policies designed to generally reduce risk in which climate change may be one of multiple rationales for adaptation, including statements of recognition on the need for developing response options and groundwork action to inform and prepare for adaptation (Tompkins et al. 2010). Such an approach reflects recognition that adaptation is a process of multiple stages, may be most effective when mainstreamed into ongoing policy priorities, and involves addressing the broader socioeconomic determinants of climate vulnerability (Dovers 2009). Both perspectives offer diverse and complimentary perspectives on the state of adaptation and also entail risks. The broad definition risks capturing symbolic policies with limited impact on vulnerability; the narrow definition may fail to capture important capacity building activities essential for vulnerability reduction. For this reason, and to minimize bias that relying on single definitions may bring, a diversity of definitional starting points are essential to bring multiple lenses from which to view adaptation progress.

The importance of consistency considerations in research design has not been widely addressed in the scholarship, with the majority of tracking studies providing limited operational detail beyond basic definitions of adaptation, limiting the ability for comparative analysis, for monitoring progress over time, and for study replication. Furthermore, studies typically identify policies/programs as adaptations if explicitly identified as such in the data source being used, but this creates challenges for consistency given the often limited detail given on how and for what purposes an adaptation was originally defined as such. Particularly, if monitoring change in adaptation over time, but also for cross case comparison, what is promoted as "adaptation" may differ widely depending on current scientific and policy norms and political factors. Exceptions include Lesnikowski et al. $(2011,2013)$ in their work documenting adaptation in the health sector, who outline detailed and explicit criteria by which policy responses are classified as adaptations, with distinction made between: statements of recognition which constitute the most basic demonstration that countries have identified climate change as a problem; groundwork actions which are considered first steps necessary to inform and prepare for adaptation, but do not explicitly indicate tangible changes in policy or delivery of government services (e.g., vulnerability assessments, research on adaptation options, conceptual tools, stakeholder and networking opportunities); and adaptation actions which refer to tangible changes in response to predicted or experienced impacts of climate change. Similarly, at a conceptual level, Dupuis and Biesbroek (2013a) propose a typology by which adaptation can be identified and characterized by the policy's intentionality and substantiality.

\subsection{Comparability}

A fundamental component of systematically tracking adaptation is that methods are guided by empirical sampling techniques. This necessitates a comparable unit of analysis: who or what, exactly, is being compared? Existing literature provides a range of case studies of adaptation from cities, countries, regions, and institutions. Comparing city-level to country-level 
adaptation initiatives (unless explicitly focusing on cross-jurisdictional patterns), however, is conceptually equivalent to comparing apples and oranges. To measure progress, adaptation tracking initiatives must define a spatial and temporal unit of analysis, or denominator, from which adaptation metrics can be reasonably compared. This might involve evaluating nationallevel adaptation progress among nations over the past 5 years or comparison of municipal adaptation programming for a defined period of time. Efforts to track adaptation have focused on particular sectors (e.g., health, private sector), regions (e.g., high-income nations, continents, high-risks nations, urban areas, mountain regions), and institutions (Heidrich et al. 2013; Mannke 2011; Lesnikowski et al. 2011, 2013; Surminski 2013; Tompkins et al. 2010; GagnonLebrun and Agrawala 2007; Keskitalo 2010; Poutiainen et al. 2013; Sovacool et al. 2012; Reckien et al. 2014; Ford et al. 2014; McDowell et al. 2014). This is invariably complicated where there are differing jurisdictions - comparing adaptation among global cities where some cities have greater devolved power for adaptation programming than others, for example. Similarly, comparing adaptation across nations is complicated by different jurisdictional structures and sizes: the Canadian federal mandate, for example, is more directed towards assisting lower level jurisdictions by providing information, resources, and guidance, compared to many European nations where national governments have a much strong role in supporting actual adaptation actions (Dickinson and Burton 2011; Isoard 2011).

Similarly, selection of data sources for adaptation tracking should be guided by empirical sampling approaches to ensure a representative sample from which to infer trends in adaptation over time. While there is likely much literature and data on adaptation among leading nations, cities, and institutions from which adaptation can be evaluated, if we are interested in general adaptation progress, then we must also include laggards in our datasets. Herein, reporting bias will continue to be a challenge for adaptation tracking: does a lack of publically available data or information on adaptation activities reflect poor adaptation progress or simply poor reporting? More standardized guidelines for collection of adaptation indicators with universal and consistent reporting would dramatically enhance access to comparable adaptation datasets at the national level and limit the impacts of reporting bias (Lesnikowski et al. 2014).

While more comparable datasets guided by efforts to systematically and empirically compare adaptation are emerging, there is negligible focus on adaptation progress over time. Adaptation tracking should therein aim not only to compare between units of analysis (e.g., nations) but also monitor change and progress. This requires longitudinal data reporting indicators of adaptation on a yearly or periodic basis (e.g., every 5 years). A snapshot of greenhouse gas emissions for a single year would be considered unsatisfactory in the context of tracking and monitoring mitigation, and the same must apply to adaptation. While no adaptation baseline exists, adaptation can at minimum be conceptualized through evaluation of progress and establishment of identifiable and comparable milestones.

An important component of comparability is also transparency in the methodology used for adaptation tracking. This is necessary to underpin longitudinal analysis of adaptation progress and comparison across cases, to facilitate use of baseline data by other research groups, to ensure consistency, and to allow independent replication of results.

\subsection{Comprehensiveness}

Our ability to infer generalizable trends and patterns and compare across nations or regions necessitates datasets large enough and with enough detail to capture a range of adaptation experiences, outcomes, and progress. Comprehensiveness herein reflects the extent to which data are available for a large number of countries, regions, or other units of analysis, and, for purposes of longitudinal assessment, are updated over time. While qualitative research will 
continue to play a critical role in exploring the depth of adaptation processes in specific contexts, there is significant value in developing datasets sufficiently comprehensive to allow quantitative analysis and an exploration of the breadth of adaptation progress across nations, using systematic approaches and comparable, consistent indicators. This presents challenges given that standardized and comprehensive data sources for an adaptation context are often unavailable (Table 3). Lesnikowski et al. (2014), for example, in their global analysis of national-level adaptation based on reporting in UNFCCC National Communications, were only able to focus on 117/195 nations due to a lack of recent reporting by many low- and middle-income countries (including large nations such as China). This reflects the risk that information on adaptation may be least available from global regions with the greatest vulnerability and need for adaptation.

As noted above for comparability, the critical factor in ensuring comprehensiveness is that adaptation datasets are, to the greatest degree possible, developed and evaluated using principles of empirical sampling. This implies not only that we have comparable data for countries (or other unit of analysis) in our dataset but also that we have as complete - and representative - a dataset as possible if we want to infer results for broader insight. Research focused on adaptation challenges and progress in developed nations certainly contributes to our understanding of adaptation, but there is an implicit bias towards the low hanging fruit regions or topics for which data are more available and voluminous. There is, for example, a research gap in our understanding of adaptation action and progress in middle income nations (Berrang-Ford et al. 2011), few datasets of adaptation in global cities which include a large and representative number of low-income cities (Araos et al., in review), and the great majority of adaptation data sources which include only a sample of regions or jurisdictions among those to which we would like to infer. The National Communications (NCs) to the UNFCCC are excellent and relatively comparable sources of adaptation information yet are largely available on a longitudinal basis only among higher-income nations. Adaptation information in the National Adaptation Programmes of Action (NAPAs) in contrast is ad hoc, only sporadically updated, and often aspirational. The potential for the NCs to provide a systematic database of global adaptation progress is thus constrained by the absence of comprehensive inclusion of all - or at least a representative sample of -nations. A more strategic approach to systematic adaptation tracking should seek to identify gaps in information or coverage and intentionally collect data for these regions or areas.

There are two options to seeking more comprehensive adaptation data sources. First, we must aspire to explicitly integrate comprehensiveness as a sampling strategy when developing new data sources. Here again, more standardized national reporting (e.g., through the UNFCCC) that focuses on adaptation indicators would substantially enhance our ability to assemble larger datasets to track global and regional adaptation more systematically. Organizations and researchers seeking to systematically track adaptation should ask: To what extent are the observations in this dataset internally and externally valid for making broader inferences? Who or what is excluded from this dataset, and to what extent might this affect the nature or generalizability of results to inform broader insight? Secondly, we should seek innovative data sources that provide more comprehensive access to adaptation information that is not readily available through standard reporting structures. Surveying policy makers and practitioners is one potential alternative approach to relying on publically available information, and Massey et al. (2014) survey elite policy makers to document adaptation policies and programs taking place in 36 European nations. The difficulty of getting sufficient response rates within and across nations to develop necessary insights, however, was identified as a major challenge in this work, a challenge likely to be compounded for global scale studies 
where multiple languages need to be spoken (noting Google translate can often be effectively used for information online). Another alternative would be to leverage new opportunities via the rapidly evolving Web 2.0, including automated web scraping, crowd sourcing, and data mining approaches. These tools remain relatively unexplored and undeveloped yet present potentially new avenues to track adaptation perceptions and activities outside of formal governmental sectors and governance structures.

\subsection{Coherence}

A great challenge for adaptation tracking is developing measureable indicators that reflect substantive adaptation. Methods should thus aim to be coherent with our existing understanding of what constitutes real adaptation. For purposes of measuring adaptation progress, for example, it is important that tracking approaches go beyond documenting the number of adaptations, widely used as a basis for measuring progress, to also capture the substance of policy development: the quantity of adaptations observed is not necessarily indicative of progress towards a more adaptable society, and adaptation efforts may be either maladaptive or merely labeled as adaptation without substantive impact (Knill et al. 2012; Ford et al. 2013; Hupe et al. 2014; Dupuis and Biesbroek 2013a; Massey et al. 2014). Such aspirations for indicators that reflect deeper and more critical aspects of adaptation success may be difficult to find in practice and impossible to access in a comparable and comprehensive beyond disparate case studies, however. There is a risk, therefore, that in seeking comparable and comprehensive adaptation data, we unintentionally water down the quality (coherence) of our measures.

This methodological challenge should not prevent adaptation tracking efforts from seeking to find measureable indicators that reflect substantive aspects of adaptation coherent with qualitative and theoretical research. One such approach could involve examining the adequacy of documented policies and programs against identified adaptation commitments, goals, and needs and has been used to compare and monitor responses across UN nations on various components of social policy (e.g., labor conditions, poverty alleviation) (Earle et al. 2011; Heymann et al. 2011; Heymann and McNeill 2013). In an adaptation context, this could involve evaluating adaptations against the types of risks addressed and relevance vis-à-vis projected changes, targeting of vulnerable populations, stage of intervention, and extent to which future risks are considered, or involve evaluating if adaptations are targeting governance structures and processes that determine the presumed ability of nations to adapt (i.e., adaptation readiness) (Ford et al. 2013). Lesnikowski et al. (2013), for example, develop an adaptation index based on stage of adaptation reported in UNFCCC National Communications (statement of recognition, groundwork, action), while Heidrich et al. (2013) develop a climate change preparedness score based on breadth of measures reported using documentation on climate policy in urban areas in the UK. Such indices can be used to track adaptation over time and across nations and can underpin analysis of drivers of adaptation action (Berrang-Ford et al. 2014).

Dupuis and Biesbroek (2013a), however, argue that more theoretically informed indicators of progress are needed that more substantially capture effectiveness alongside actions and propose a proximity-to-target approach where documented adaptations can be compared to a theoretically derived model of successful adaptation. Here, adaptation is conceptualized by intentionality, capturing the extent to which policies are purposefully designed or changed to manage the impacts of climate change and reduce vulnerability, and substantiality, capturing the extent to which a policy contributes to actually reducing vulnerability or benefiting from climate change opportunities. To be meaningful and coherent with adaptation research, adaptation tracking should seek to be guided by 
theory and identify thoughtful proxies of adaptation progress. To this end, achieving coherence of indicators with our theoretical understanding of what constitutes real adaptation may be unfeasible in practice. There is an inevitable trade-off between the breadth of comparable and comprehensive datasets and the substantive depth (coherence) sought to investigate adaptation progress that goes beyond simple metrics and crude indicators of adaptation.

\section{Conclusion}

Over the last decade, adaptation has emerged as a central component of climate policy, increasingly prioritized in government policy across scales, by NGOs, international institutions, and the private sector. Our understanding on the current state of adaptation globally, however, remains limited to snapshots provided by global/national assessments and case studies from different regions. An emerging adaptation tracking subfield has also begun to develop and has been influential in creating a baseline understanding of adaptation across regions, nations, and sectors, piloting different approaches and methods. Yet discrepancies and inconsistencies in work that has been completed are indicative of the immaturity of the adaptation tracking field. With the creation of new funding streams and programs for adaptation at international and national levels, there is a need for systematic, rigorous, and transparent approaches to adaptation tracking research focused on developing indicators by which the current state of adaptation can be characterized, monitored, and compared.

In this paper, we propose key components of research design that should be used to guide adaptation tracking studies. The work advances further a nascent scholarship assessing adaptation progress, specifically focusing on components of research design necessary for longitudinal analysis, comparison across nations, and the development of adaptation indicators. Herein, indicators provide a systematic and standardized means for characterizing the state of adaptation at a specific point in time and from which future progress can be monitored, evaluated, and communicated. In a tracking context, indicators can provide a direct measure of adaptations taking place, and contrast to vulnerability where the use of indicators to characterize and monitor trends has been widely critiqued, reflecting the nature of vulnerability as a potential state of affairs and lack of agreement on determinants of vulnerability (Hinkel 2011; Barnett et al. 2008; Klein 2009). It has been argued in the general scholarship, however, that indicators may mislead policy, directing attention to interventions that can be measured and focusing on improving rankings as opposed to developing policies that are effective in actually addressing a problem. The development of indicators also often involves trading breadth for depth, thus limiting the ability to capture whether effective adaptations are being implemented, while questions of equity and power arise around who defines adaptation. For these reasons, we emphasize that developing adaptation indicators for global scale tracking purposes must occur in parallel with qualitative studies examining adaptations in specific places; together, both type of study can make a powerful contribution towards informing adaptation policy priorities. The need for such diversity in methodological approaches for adaptation has not yet been fully articulated, with the field remaining dominated by context specific studies (Swart et al. 2014; Preston et al. 2014).

Systematic tracking also requires standardized reporting on adaptation. Mitigation reporting already consists of well-developed methodologies for inventorying emissions, yet only a limited number of data sources collect information on adaptation in a rigorous, consistent, transparent, timely, and comprehensive manner. National Communications (NCs) to the UNFCCC, for instance, have been employed in a number of studies, valued for their 
documentation of climate policy action across nations, over time, and according to specific guidelines, and perhaps offer one of the most comprehensive global datasets for adaptation tracking that we have. Nevertheless, NCs were not designed for tracking purposes per se, remain dominated by mitigation, are of varying quality in their documentation of adaptation, focus predominantly on the national level, and are insufficient for detailed analysis. The development of robust reporting systems to create a global adaptation inventory is therefore urgently needed, with the UNFCCC ideally suited to take leadership role in creating a standardized adaptation reporting platform.

These are critical times for adaptation, which has become firmly established in climate policy. Yet adaptation science remains the poor cousin of mitigation science, with significant differences in understanding and scientific development between the two. Adaptation tracking is one such area of divergence, where our ability to answer the question: are we adapting to climate change is limited by an absence of tools, datasets, and baseline research. Addressing these gaps should be a priority for future work, with the 4Cs proposed here providing a starting point for systematically examining adaptation progress.

Acknowledgments This work was supported by research grants from the Social Sciences and Humanities Research Council of Canada. Thanks to Malcolm Araos and Stephanie Austin who provided comments on the paper and anonymous reviewers who provided constructive feedback.

Open Access This article is distributed under the terms of the Creative Commons Attribution License which permits any use, distribution, and reproduction in any medium, provided the original author(s) and the source are credited.

\section{References}

Adger WN, Barnett J (2009) Four reasons for concern about adaptation to climate change. Environ Plann A 41: 2800-2805. doi:10.1068/a42244

Adger WN, Arnell NW, Tompkins EL (2005) Successful adaptation to climate change across scales. Glo Environ Chang-Human Policy Dimens 15:77-86. doi:10.1016/j.gloenvcha.2004.12.005

Baettig MB, Bernauer T (2009) National institutions and global public goods: are democracies more cooperative in climate change policy? Int Organ 63:281-308. doi:10.1017/s0020818309090092

Barnett J, Lambert S, Fry I (2008) The hazards of indicators: insights from the environmental vulnerability index. Ann Assoc Am Geogr 98:102-119

Bassett TJ, Fogelman C (2013) Deja vu or something new? The adaptation concept in the climate change literature. Geoforum 48:42-53. doi:10.1016/j.geoforum.2013.04.010

Berrang-Ford L, Ford JD, Patterson J (2011) Are we adapting to climate change? Glob Environ Chang 21:25-33

Berrang-Ford L, Ford JD, Lesnikowski A, Poutiainen C, Barrera M, Heymann SJ (2014) What drives national adaptation? A global assessment. Clim Chang 124:441-450. doi:10.1007/s10584-014-1078-3

Berrang-Ford L, Pearce T, Ford JD (2015) Systematic review approaches for global environmental change research. Regional Environmental Change.

Biagini B, Bierbaum R, Stults M, Dobardzic S, McNeeley SM (2014) A typology of adaptation actions: A global look at climate adaptation actions financed through the Global Environment Facility. Global Environmental Change-Human and Policy Dimensions 25:97-108

Biesbroek GR, Swart RJ, Carter TR, Cowan C, Henrichs T, Mela H, Morcecroft MD, Rey D (2010) Europe adapts to climate change - comparing national adaptation strategies. Glob Environ Chang 20: $440-450$

Biesbroek GR, Klostermann JEM, Termeer CJAM, Kabat P (2013) On the nature of barriers to climate change adaptation. Reg Environ Chang 13:1119-1129. doi:10.1007/s10113-013-0421-y

Bizikova L, Parry J, Dekens J, Echieverria D (2015) Review of key initiatives and approaches to adaptation planning at the national level in semi-arid areas. Reg Environ Chang 
Bradley GL, Reser JP, Glendon AI, Ellul MC (2014) Distress and coping in response to climate change. In: Kaniasty K, Buchwald P, Howard S, Moore K (eds) Stress and anxiety applications to social and environmental threats, psychological wellbeing, occupational challenges, and developmental psychology. Logos verlag, Berlin

Brooks N, Anderson S, Ayers J, Burton I, Tellam I (2011a) Tracking adaptation and measuring development. Clim Chang Work Pap No 1

Brooks N, Anderson S, Ayers J, Burton I, Tellam I (2011b) Tracking adaptation and measuring development in: (IIED) iIfEaD (ed) IIED Clim Chang Work Paper No 1

Brooks N, Anderson S, Burton I, Fisher S, Rai N, Tellam I (2013) An operational framework for Tracking Adaptation and Measuring Development (TAMD). In: http://pubs.iied.org/10038IIED.html) ICCWPNAf (ed)

Burton P, Mustelin J (2013) Planning for climate change: is greater public participation the key to success? Urban Policy Res 31:399-415. doi:10.1080/08111146.2013.778196

Carmin J, Nadkarni N, Rhie C (2012) Progress and challenges in urban climate adaptation planning: results of a global survey in: Cambridge MM (ed)

Red Cross Red Crescent (2013) Minimum standards for local climate smart disaster risk reduction. Red Cross/ Red Crescent Climate Centre, The Hague

de Bruin K, Dellink RB, Ruijs A, Bolwidt L, van Buuren A, Graveland J, de Groot RS, Kuikman PJ, Reinhard S, Roetter RP, Tassone VC, Verhagen A, van Ierland EC (2009) Adapting to climate change in The Netherlands: an inventory of climate adaptation options and ranking of alternatives. Clim Chang 95:2345. doi:10.1007/s10584-009-9576-4

Dickinson T, Burton I (2011) Adaptation to climate change in Canada: a multi-level mosaic. In: Ford JD, Berrang-Ford L (eds) Climate change adaptation in developed nations: from theory to practice. Springer, Dordrecht, pp 103-118

Dolsak N (2001) Mitigating global climate change: why are some countries more committed than others? Policy Stud J 29:414-436

Dolsak N (2009) Climate change policy implementation: a cross-sectional analysis. Revi Policy Res 26:551-570. doi:10.1111/j.1541-1338.2009.00405.x

Dovers S (2009) Normalizing adaptation. Glob Environ Chang 19:4-6

Dupuis J, Biesbroek R (2013a) Comparing apples and oranges: the dependent variable problem in comparing and evaluating climate change adaptation policies. Glob Environ Chang-Human Policy Dimens 23:1476-1487. doi:10.1016/j.gloenvcha.2013.07.022

Dupuis J, Knoepfel P (2013b) The adaptation policy paradox: the implementation deficit of policies framed as climate change adaptation. Ecol Soc 18. doi: 10.5751/es-05965-180431

Eakin HC, Lemos MC, Nelson DR (2014) Differentiating capacities as a means to sustainable climate change adaptation. Glob Environ Chang

Earle A, Mokomane Z, Heymann J (2011) International perspectives on work-family policies: lessons from the world's most competitive economies. Futur Child 21

Editorial (2013) Adapting to climate change. Nat Clim Chang 3(11):939

Eisenack K, Stecker R (2012) A framework for analyzing climate change adaptations as actions. Mitig Adapt Strateg Glob Chang 17:243-260. doi:10.1007/s11027-011-9323-9

Ford JD, Berrang-Ford L, Patterson J (2011) A systematic review of observed climate change adaptation in developed nations. Clim Chang Lett. doi:10.1007/s10584-011-0045-5

Ford JD, Berrang-Ford L, Lesnikowski A, Barrera M, Heymann SJ (2013) How to track adaptation to climate change: a typology of approaches for national-level application. Ecol Soc 18. doi:10.5751/es-05732-180340

Ford JD, McDowell G, Jones J (2014) The current status of climate change adaptation in the Arctic. Environl Res Lett 9 104005. doi:10.1088/1748-9326/9/10/104005

Fussel HM (2008) Assessing adaptation to the health risks of climate change: what guidance can existing frameworks provide? Int J Environ Health Res 18:37-63. doi:10.1080/09603120701358416

Gagnon-Lebrun F, Agrawala S (2007) Implementing adaptation in developed countries: an analysis of progress and trends. Clim Pol 7:392-408. doi:10.1080/14693062.2007.9685664

Hardee K, Mutunga C (2010) Strengthening the link between climate change adaptation and national development plans: lessons from the case of population in National Adaptation Programmes of Action (NAPAs). Mitig Adapt Strateg Glob Chang 15:113-126. doi:10.1007/s11027-009-9208-3

Heidrich O, Dawson RJ, Reckien D, Walsh CL (2013) Assessment of the climate preparedness of 30 urban areas in the UK. Clim Chang 120:771-784. doi:10.1007/s10584-013-0846-9

Heymann J, McNeill K (2013) Children's chances: how countries can move from surviving to thriving. Harvard University Press, Cambridge

Heymann J, Raub A, Earle A (2011) Creating and using new data sources to analyze the relationship between social policy and global health: the case of maternal leave. Public Health Rep 126 
Hinkel J (2011) "Indicators of vulnerability and adaptive capacity": towards a clarification of the science-policy interface. Glob Environ Chang-Human Policy Dimens 21:198-208. doi:10.1016/j.gloenvcha.2010.08.002

Hupe P, Hill, M., Nangia M (2014) Studying implementation beyond deficit analysis: the top-down view reconsidered. Public Policy Adm

IPCC (2007) Climate change 2007: impacts, adaptation and vulnerability. Working Group II Contribution to the Intergovernmental Panel on Climate Change Fourth Assessment Report, Geneva

Isoard S (2011) Perspectives on adaptation to climate change in Europe. In: Ford JD, Berrang-Ford L (eds) Change adaptation in developed nations: from theory to practice. Springer, Dordrecht, pp 51-68

Kamau JW, Mwaura F (2013) Climate change adaptation and EIA studies in Kenya. Int J Clim Chang Strateg Manag 5:152-165. doi:10.1108/17568691311327569

Keskitalo ECH ed (2010). The development of adaptation policy and practice in Europe: multi-level governance of climate change. Springer Verlag, Berlin

Khan MR, Roberts JT (2013) Adaptation and international climate policy. Wiley Interdisc Rev-Clim Chang 4: 171-189. doi:10.1002/wcc. 212

Klein RJT (2009) Identifying countries that are particularly vulnerable to the adverse effects of climate change: an academic or political challenge? Carbon Clim Law Rev 3:284-291

Klein RJT, Moehner A (2011) The Political dimension of vulnerability: implications for the green climate fund. Ids Bull-Inst Dev Stud 42. doi: 10.1111/j.1759-5436.2011.00218.x

Knill C, Schulze K, Tosun J (2012) Regulatory policy outputs and impacts: exploring a complex relationship. Regul Governance 6:427-444. doi:10.1111/j.1748-5991.2012.01150.x

Krysanova V, Dickens C, Timmerman J, Varela-Ortega C, Schlueter M, Roest K, Huntjens P, Jaspers F, Buiteveld H, Moreno E, Carrera JP, Slamova R, Martinkova M, Blanco I, Esteve P, Pringle K, Pahl-Wostl C, Kabat P (2010) Cross-comparison of climate change adaptation strategies across large river basins in Europe, Africa and Asia. Water Resour Manag 24:4121-4160. doi:10.1007/s11269-010-9650-8

Lamhauge N, Lanzi E, Agrawala S (2013) The use of indicators for monitoring and evaluation of adaptation: lessons from development cooperation agencies. Clim Dev 5:229-241. doi:10.1080/17565529.2013.801824

Lesnikowski AC, Ford JD, Berrang-Ford L, Paterson JA, Barrera M, Heymann SJ (2011) Adapting to health impacts of climate change: a study of UNFCCC Annex I parties. Environ Res Lett 6 doi:10.1088/17489326/6/4/044009

Lesnikowski AC, Ford JD, Berrang-Ford L, Barrera M, Berry P, Henderson J, Heymann SJ (2013) National-level factors affecting planned, public adaptation to health impacts of climate change. Glob Environ ChangHuman Policy Dimens 23:1153-1163. doi:10.1016/j.gloenvcha.2013.04.008

Lesnikowski A, Ford JD, Berrang-Ford L, Barrera M, Heymann J (2014) How are we adapting to climate change? A systematic approach to measuring reported adaptation at the national level. Mitig Adapt Strateg Glob Chang

Mannke F (2011) Key themes of local adaptation to climate change: lessons from mapping community-based initiatives in Africa In: Leal Filho W (ed) Experiences of climate change adaptation in Africa. Springer, pp 17-32

Massey E, Bergsma E (2008) Assessing adaptation 27 European countries. IVM, Amsterdam

Massey E, Huitema D (2013) The emergence of climate change adaptation as a policy field: the case of England. Reg Environ Chang 13:341-352. doi:10.1007/s10113-012-0341-2

Massey E, Biesbroek R, Huitema D, Jordan A (2014) Climate policy innovation: the adoption and diffusion of adaptation policies across Europe. Glob Environ Chang

McDowell G, Stephenson E, Ford JD (2014) Adaptation to climate change in glaciated mountain regions. Clim Chang 126:77-91

Mimura N, Pulwarty R (2014) Chapter 15: Adaptation planning and implementation In: Working Group II of the Fifth Assessment Report of the Intergovernmental Panel on Climate Change

Moss RH, Meehl GA, Lemos MC, Smith JB, Arnold JR, Arnott JC, Behar D, Brasseur GP, Broomell SB, Busalacchi AJ, Dessai S, Ebi KL, Edmonds JA, Furlow J, Goddard L, Hartmann HC, Hurrell JW, Katzenberger JW, Liverman DM, Mote PW, Moser SC, Kumar A, Pulwarty RS, Seyller EA, Turner BL II, Washington WM, Wilbanks TJ (2013) Hell and high water: practice-relevant adaptation science. Science 342:696-698. doi:10.1126/science.1239569

Mukheibir P, Ziervogel G (2008) Framework for developing a municipal adaptation plan In: weADAPT (ed)

Murray CJL, Lopez AD, Jamison DT (1994) The global burden of disease in 1990 - summary results, sensitivity analysis and future-directions. Bull World Health Organ 72:495-509

Murtinho F, Hayes TM (2012) Adaptation in resource-dependent communities: a call for greater methodological clarity in adaptation field research. Soc Nat Resour 25:513-522. doi:10.1080/08941920.2011.604068

Noble I, Huq S (2014) Chapter 14: Adaptation needs and options. In: Working Group II of the Intergovernmental Panel on Climate Change Fifth Assessment Report

O’Brien K (2012) Global environmental change II: from adaptation to deliberate transformation. Prog Human Geogr 36. doi: 10.1177/0309132511425767 
Panic M, Ford JD (2013) A review of national-level adaptation planning with regards to the risks posed by climate change on infectious diseases in 14 OECD nations. Int J Environ Res Public Health 10:7083-7109. doi:10.3390/ijerph10127083

PBL (2013) Trends in global CO2 emissions: 2013 report In: PBL Netherlands Environmental Assessment Agency, Institute for Environment and Sustainability of the European Commission's Joint Research Centre

Porter JJ, Dessai S, Tompkins E (2014) What do we know about UK household adaptation to climate change? A systematic reivew. Clim Chang 127:371-379. doi:10.1007/s10584-014-1252-7

Poutiainen C, Berrang-Ford L, Ford J, Heymann J (2013) Civil society organizations and adaptation to the health effects of climate change in Canada. Public Health 127:403-409. doi:10.1016/j.puhe.2013.02.004

Preston BL, Mustelin J, Maloney MC (2014) Climate adaptation heuristics and the science/policy divide. Mitig Adapt Strateg Glob Chang. doi:10.1007/s11027-013-9503-x

Reckien D, Flacke J, Dawson RJ, Heidrich O, Olazabal M, Foley A, Hamann JJP, Orru H, Salvia M, Hurtado SDG, Geneletti D, Pietrapertosa F (2014) Climate change response in Europe: what's the reality? Analysis of adaptation and mitigation plans from 200 urban areas in 11 countries. Clim Chang 122:331-340. doi:10. 1007/s10584-013-0989-8

Sherman M, Ford J (2014) The role of stakeholder engagement in affecting the performance of adaptation interventions in developing nations: An evaluation of GEF-funded projects. Clim Policy 14(3):417-441

Smit B, Burton I, Klein RTJ, Street R (1999) The science of adaptation: a framework for assessment. Mitig Adapt Strateg Glob Chang 4:199-213

Smit B, Burton B, Klein RJT, Wandel J (2000) An anatomy of adaptation to climate change and variability. Climate Change 45:223-251

Smith MS, Horrocks L, Harvey A, Hamilton C (2011) Rethinking adaptation for a 4 degrees C world. Philos Trans Royal Soc-Math Phys Eng Sci 369. doi: 10.1098/rsta.2010.0277

Smithers J, Smit B (1997) Human adaptation to climatic variability and change. Glob Environ Chang 7:129-146

Sovacool BK, D'Agostino AL, Meenawat H, Rawlani A (2012) Expert views of climate change adaptation in least developed Asia. J Environ Manag 97:78-88. doi:10.1016/j.jenvman.2011.11.005

Sud R, Mishra A, Varma N, Bhadwal S (2015) Adaptation policy and practice in densely populated glacier-fed river basins of South Asia: a systematic review. Reg Environ Chang

Surminski S (2013) Private sector adaptation to climate risk. Nat Clim Chang 3(11):943-945

Swart R, Biesbroek R, Lourenco TC (2014) Science of adaptation to climate change and science for adaptation. Front Environ Sci 2. doi:10.3389/fenvs.2014.00029

Swim JK, Stern PC, Doherty TJ, Clayton S, Reser JP, Weber EU, Gifford R, Howard GS (2011) Psychology's contributions to understanding and addressing global climate change. Am Psychol 66:241-250. doi:10.1037/ a0023220

Tompkins EL, Adger WN, Boyd E, Nicholson-Cole S, Weatherhead K, Arnell N (2010) Observed adaptation to climate change: UK evidence of transition to a well-adapting society. Glob Environ Chang-Human Policy Dimens 20. doi: 10.1016/j.gloenvcha.2010.05.001

Townshend T, Fankhauser S, Aybar R, Collins M, Landesman T, Nachmany M, Pavese C (2013) How national legislation can help to solve climate change. Nat Clim Chang 3:430-432

Tubi A, Fischhendler I, Feitelson E (2012) The effect of vulnerability on climate change mitigation policies. Glob Environ Chang-Human Policy Dimens 22:472-482. doi:10.1016/j.gloenvcha.2012.02.004

Villaneuva PS (2011) Learning to ADAPT: monitoring and evaluation approaches in climate change adaptation and disaster risk reduction- challenges, gaps and ways forward. SCR Discussion Paper 9. Strengthening Climate Resilience. In: Resilience SC (ed). SCR Discussion Paper 9

Yohe G, Tol RSJ (2002) Indicators for social and economic coping capacity—moving toward a working definition of adaptive capacity. Glob Environ Chang-Human Policy Dimens 12:25-40 